ISBN 978-93-84468-80-4
International Conference on Agricultural, Biological and Environmental Sciences

(ICABES-2016)

Pattaya (Thailand) Dec. 14-16, 2016

\title{
Hydrogeological Features of the Gökgöl Lake (Kulu, Konya- Central Anatolia)
}

\author{
Ali Ferat Bayram \\ Geological Engineering Department, Selçuk University, TR-42250-Konya, Turkey
}

\begin{abstract}
The Gökgöl Lake is one of the most important wetlands in Central Anatolia, and located in Kulu district of Konya. It is aimed to prove hydrogeological features and hydrological budget parameters of the Gökgöl wetland in this study. The rate of evapo-transpiration and long-term total precipitation are $362.89 \mathrm{~mm} / \mathrm{yr}$ and $383.83 \mathrm{~mm}$, respectively. The total water balance is $38.53 \mathrm{~mm} / \mathrm{yr}$ according to discharge from the well. The lake of Samsam and Gökgöl are main water body in the study area. There are also a stream connected to the Samsam Lake, a water spring and twenty three water wells for drinking and irrigation. The volume of water, depth, base slope, volumetric growth rate and water retention time of the Gökgöl are $2093326.42 \mathrm{~m}^{3}, 1.2 \mathrm{~m}$, $0.522,1,565$ and 1.47 , respectively.

The Ankara ophiolitic melange, the Karadağ volcanics and the Cihanbeyli formation are main geological units in the study area. The melange is Mesozoic in age and constitutes the basement of the study area. Impermeable and aquifuge, the ophiolitic melange includes fractured olistolithes with permeability. The Miocene Karadag volcanics are mainly composed of andesite and dacite, but rare basalt. Volcanic rocks of the unit are impermeable although they are porous. The Cihanbeyli formation has aquifer characteristics, and is composed of carbonate and clastic sedimentary rocks. However, fine clastics between coarse grain and marl cause impermeability for this formation. Hence, the Gökgöl basin covers an aquifer area of $96.8 \mathrm{~km}^{2}$, and aquifuge and akiklude area of $48 \mathrm{~km}^{2}$. Water level of the lake is getting lower day after day. The first reason of decrease is a geological phenomena: the Cihanbeyli formation constituting base of the lake sometimes leaks because of its lithology. The second one is water policy: the residents illegally use both underground and surface water by drilling and pumping for agriculture. The findings from this study show that the Gökgöl should be given more attention because it is rich in biodiversity.
\end{abstract}

Keywords: Gökgöl wetland, hydrological budget, aquifuge, aquifer, drinking and irrigation water

\section{Introduction}

In the studying field of Middle Anatolia; there are Kulu- Kozanlı wetland that is evaluated under RAMSAR Agreements, two rivers, are springs and twenty water wells. In this study, the determining of hydraulic budged parameters of Gökgöl water land that's is biovariority protection is important as the other ecosystems and its geological and hydrogeological peculiarities have been aimed. This area, according to the Thornthwaite climate type is classified of D, B, d, b3. According to the long years researches the highest winds data became $20.9 \mathrm{~m} / \mathrm{s}$ in September towards to southwest. Annual heat average is $10.3{ }^{\circ} \mathrm{C}$. the average annual precipitation in the region $883 \mathrm{~mm}$ and the lowest relative humidity 25.5 but the highest humidity is 89.7 (Fig. 1). 


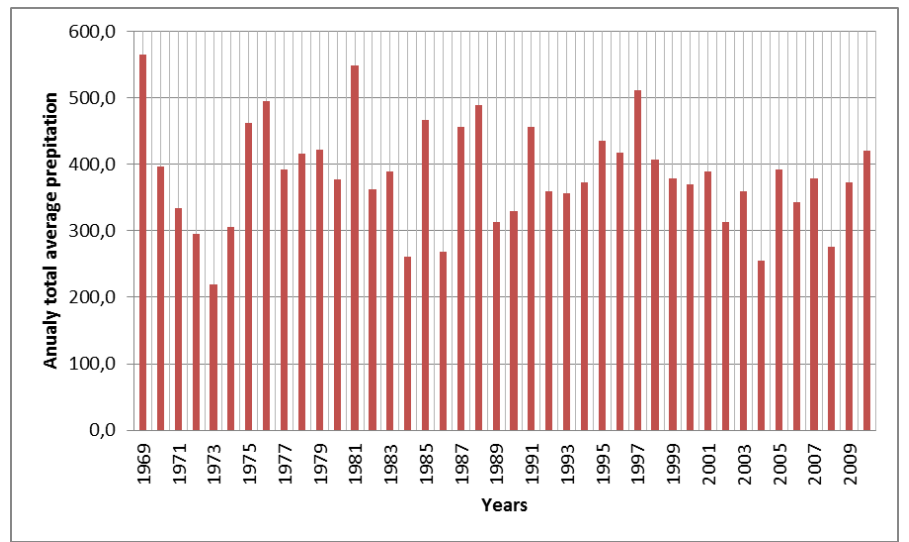

Fig. 1 Average annual precipitation

According to the months, coming of the average rain the highest level has occurred in December and the lowest level in august (Fig. 2).

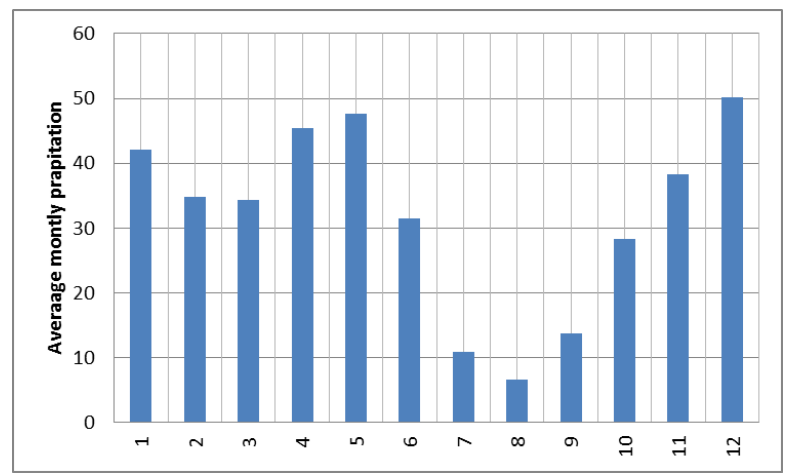

Fig. 2 According to the months, average precipitation

Evapo- transpiration: The amount of sweat evaporation according to Thornthwaite method was calculated as $363 \mathrm{~mm} / \mathrm{y}$ according to 2010 data from January to the end of March increasing of water is seen on the contrary this to the end of May to the middle of October the lack of water is seen. In addition, at the end of April it is seen that the reserve of the useful water has been used and also it is observed that the spare water has been begun to complete since October. When meteorological data which is between 1969 and 2010 monthly average is evaluated, it is seen that increasing of water continues from January to the middle of April and lack of waters between June and October, the useful spare water is consumed from the beginning of May and it's observed that since November the useful spare water is completed (Fig. 3).

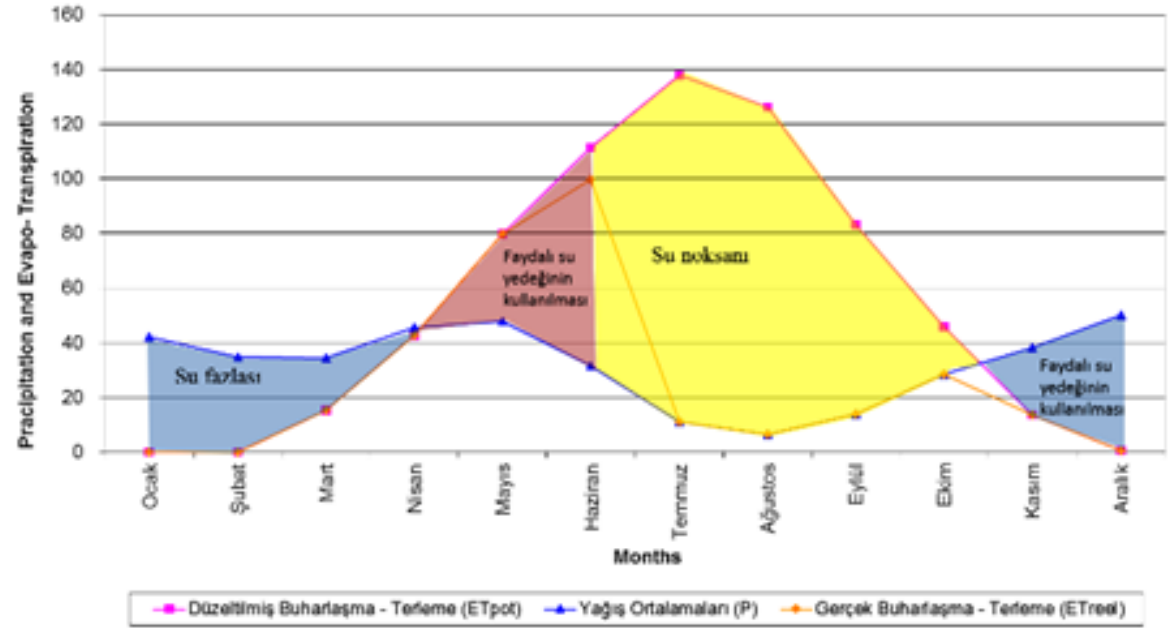

Fig. 3 According to the monthly average rain and evaporation relationship 


\section{Hydrology}

Water points that are in the studying area: Gökgöl which is the subject of study and Lake Samsam which feeds of this Lake (Gökgöl), are water spring and twenty-three wells which are open for drinking and watering.

\subsection{Lakes}

Lake Samsam which is in the northwest of the studying area becomes spring of Lake Gökgöl contains Cihanbeyli formation on its base Lake Samsam's surface measurement is $830 \mathrm{~m}^{2}$ and its evaluation altitude is $925 \mathrm{~m}^{2}$.

Lake Reservoir volume as morphometric values, coastline development index average depth floor slope volumetric rate of development is determined on the ratio of the drainage area of time and lake water holding capacity

Lake volume was measured about $2093326,43 \mathrm{~m}^{3}$

$$
K G I=\frac{L}{2 \sqrt{\pi * A o}}=\frac{6210}{2 \sqrt{3,14 * 1744438,68}}=\frac{6210}{4680,83}=1.33
$$

1- Coastline development index was learned by KGI equation.

$$
D=\frac{V}{A o} \quad \frac{2093326,42}{1744438,68}=1.2 \mathrm{~m}
$$

To lake surface area, $\mathrm{L}$ is the length of the coastline

2- Average depth (D) V is the volume of the lake here

3- Floor slope $(\mathrm{S})$

$$
S=\frac{D}{D m}=\frac{1.2}{2.3}=0.522
$$

Here it shows the maximum depth of the lake measurement

4- The volumetric rate of development $(\mathrm{Vd})$

$$
V d=3 * \frac{D}{D m}=\frac{3 * 1.2}{2.3}=1.565
$$

5- Water retention time (RT)

$$
R T=\frac{2093326.42}{1423850.4}=1.47
$$

6- Lake drainage area of the capacity ratio

$$
R=\frac{57231254.46}{2093326.42}=27.34
$$

Impermeable levels that contains Cihanbeyli formation and Gökgöl provide the ophiolitic melange accumulation of water with impermeable. However it is possible the realization of Cihanbeyli formation of water leakage crumbs of Gökgöl base.

\subsection{Rivers}

In study area, there are river that feeds Gökgöl and stream which incomes from lake Samsam and also there is a stream that becomes from Doğutepe and Karakaya resources. But as the water of this area is used for drinking, it is not active now.

Samsam Stream: it is measurements was performed by SHW (State Hydraulics Worrks) according to these measurements it was carried out by the out of Samsam, Tollar Plateau and Pazarözü. In 1990 total flowing was $130.967 \mathrm{~m}^{3} / \mathrm{s}$ and average flowing was $0,360 \mathrm{~m}^{3} / \mathrm{s}$ in 1989 total flowing was $120,024 \mathrm{~m}^{3} / \mathrm{s}$ and average flowing was $120.024 \mathrm{~m}^{3} / \mathrm{s}$. According to the measurements that become in the out of Lake Samsam, its relationship of ground water was found by $\mathrm{T}=0.827^{*} \mathrm{~A}^{0,2}$ formula. Surface and ground water flows were determined by the time 
of run out, in this formula A shows us the square of stream drainage and for the studying area this drainage was determined by $25 \mathrm{~km}^{2}$ according to this, $\mathrm{T}=1.52$ was determined (Fig 4).

Total flows that are from Samsat river and Tollar plateau is $22.834 \mathrm{~m}^{3} / \mathrm{s}$ and average flowing is $0.063 \mathrm{~m}^{3} / \mathrm{s}$ in the measurement of the river that was made on entry in to the area of the river Gökgöl, flow rate 27 1/s measured.

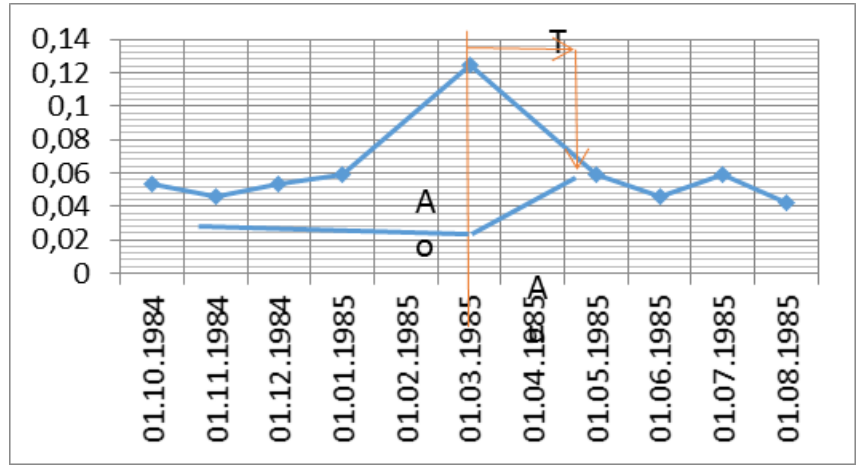

Fig. 4 Tollar plateau, in 1990, the relationship between surface and groundwater flow

For 1999 the measurements of the flows rate in the out of Gökgöl and Pazarözü total current $66.276 \mathrm{~m}^{3} / \mathrm{s}$ and average current $0.291 \mathrm{~m}^{3} / \mathrm{s}$ was measured (Fig 5).

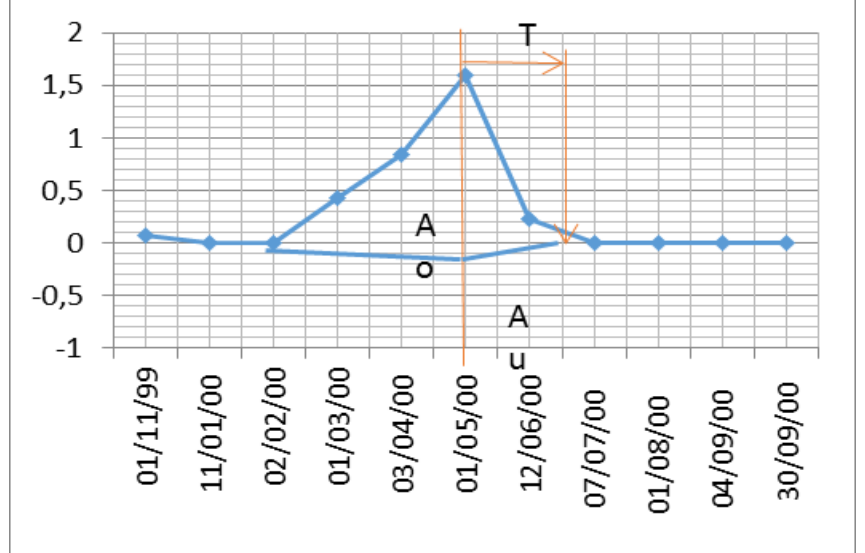

Fig. 5 In Pazarözü location for 2000 the relationship between surface and groundwater

Gölbaşı Stream: Gölbaşı springs that were in the north of Kozanlı location were created the Fountain next to the municipal building and it was directed to Gökgöl along the river from here.

\subsection{Springs}

The formation of water resources in the basin Gökgöl ophiolitic melange in the olistoliths border is possible. In the southwest study area there is a contact spring between $\mathrm{x}=36482613$ and $\mathrm{y}=4317904 \mathrm{~m}$ coordinates. This spring feeds from these olistoliths.

According to the source of a particular method of instant flow rate volume was measured as $1.25 \mathrm{l} / \mathrm{s}$. In addition to these spring, it is said to have plurality of water outlet on the flow of Gökgöl. Kozanlı north of the district centre located Gölbaşı resources has been transferred by captaging to near the building of municipilary, in addition other resources created open channels and then they are transferred into Gökgöl. According to the measurements that were made next to town hall the flow rate of spring was found as $0.666 \mathrm{l} / \mathrm{s}$.

\subsection{Water Wells}

In the study area, water level measurements were than from 23 wells the \#3 of these Wells have been drilled in olistholits located in ophiolitic melange. Other Wells receive water from the silt and Cihanbeyli formation. The number 21 of these Wells was opened by SHW and the number 14 and 15 was opened by the municipality are considered to be drinking water wells. However the number 15 of these wells hasn't been activated (Fig 6). 


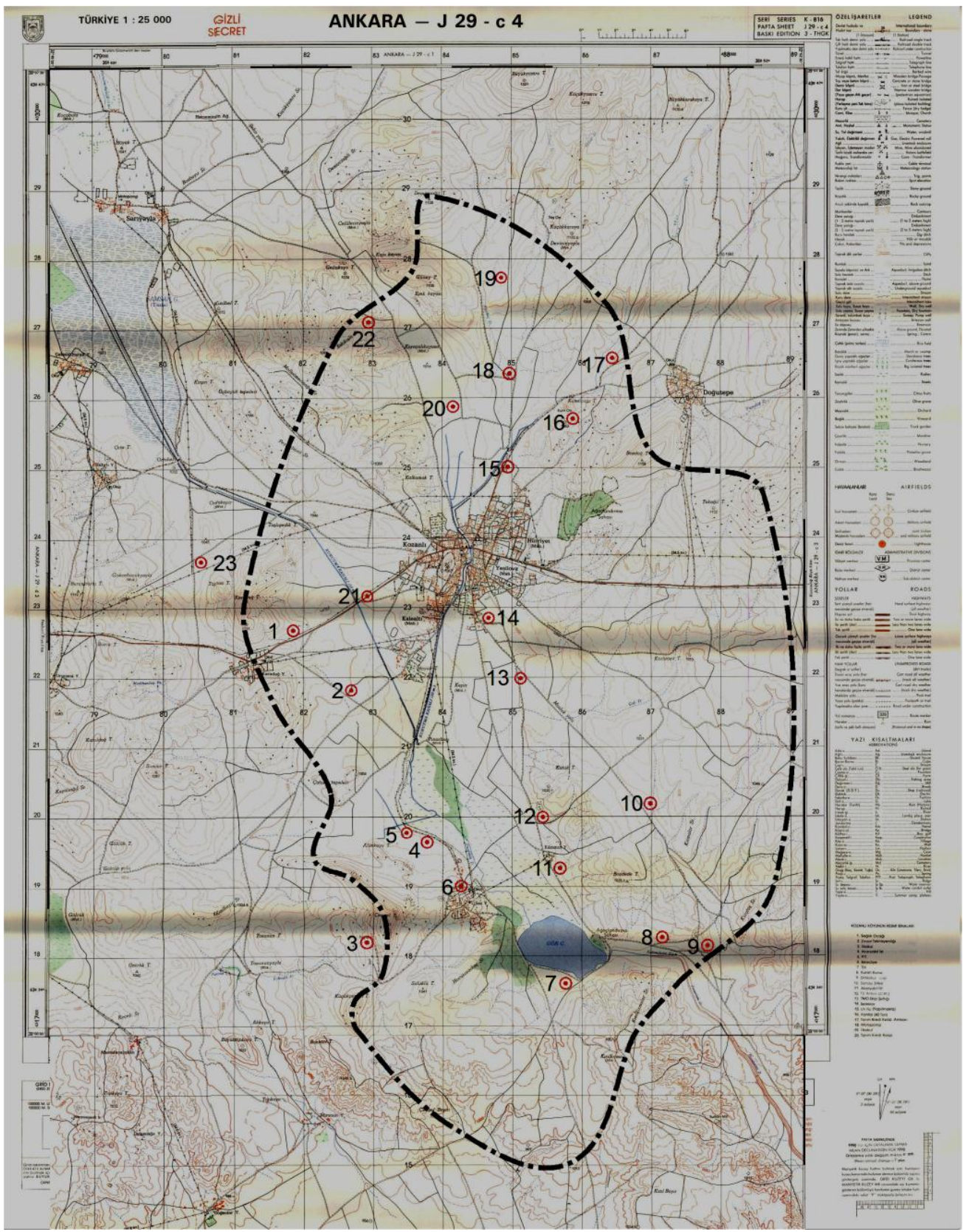

Fig. 6 Gökgöl plateau and the places of the water wells

\section{Water Budged}

Gökgöl plateau is $57.23 \mathrm{~km}^{2}$.It has the area that includes all water wells in. In this area especially in the summer semester covering the study period, the consumption of the total wells is $67.51 \mathrm{l} / \mathrm{s}$ specified flow rate $\mathrm{q}=1,092 \mathrm{l} / \mathrm{s} \mathrm{km}^{2}$.Therefore the height of the wells in Gökgöl plateau $\mathrm{h}=31.5576^{*} \mathrm{q}=31.5576^{*} 1.092=34.47 \mathrm{~mm}$.

In the hydrological basic formula $(\mathrm{P})=$ evaporation-transpiration $(\mathrm{ET})+\mathrm{current}(\mathrm{flow})(\mathrm{A})$ is determined.

Total rainfall is $383.83 \mathrm{~mm}$ to the long years. Total evaporation-transpiration is $310.70 \mathrm{~mm}$ thus considering that the production made in the wells, all the water budged the plateau is $\mathrm{B}=\mathrm{P}-(\mathrm{ET}+\mathrm{h})=383.83$ $(310.83+34.47)=38.53 \mathrm{~mm} / \mathrm{yr}$.

Thus, $38.53 \mathrm{~mm}$ excess water in a year will feed the flow of surface and groundwater. Water resources in the region are not included in the water budged because the water resources remain the outside of the plateau. 


\section{Important Introduction}

Gökgöl plateau that is the studying area and its surrounding has impermeable ophiolite melange. Olistholits which are located in these units that are aquifuge, they have gained permeable speciality because of the fractured feature. Although Karadağ volcanits partially have the containing of water they have impermeable characters [1, $2,3,4]$.

Cihanbeyli formation which becomes clastic sedimentary rocks has aquifer. However, the thin clastics among the large clastics and marn makes this formation impermeable. Thus although Gökgöl plateau is approximately $96.8 \mathrm{~km}^{2}$ aquifer, it covers $48 \mathrm{~km}^{2}$ area as being aquifuge and akiklude quality. The impermeable levels in Cihanbeyli formation that is located an Gökgöl Plateau and ophiolitic melange [5] that has the feature of impermeable and bottom of this unit provide accumulation of water it's also possible that water leakage becomes from the clastic of Cihanbeyli formation which are bottom of the Gökgöl plateau (Fig 7).

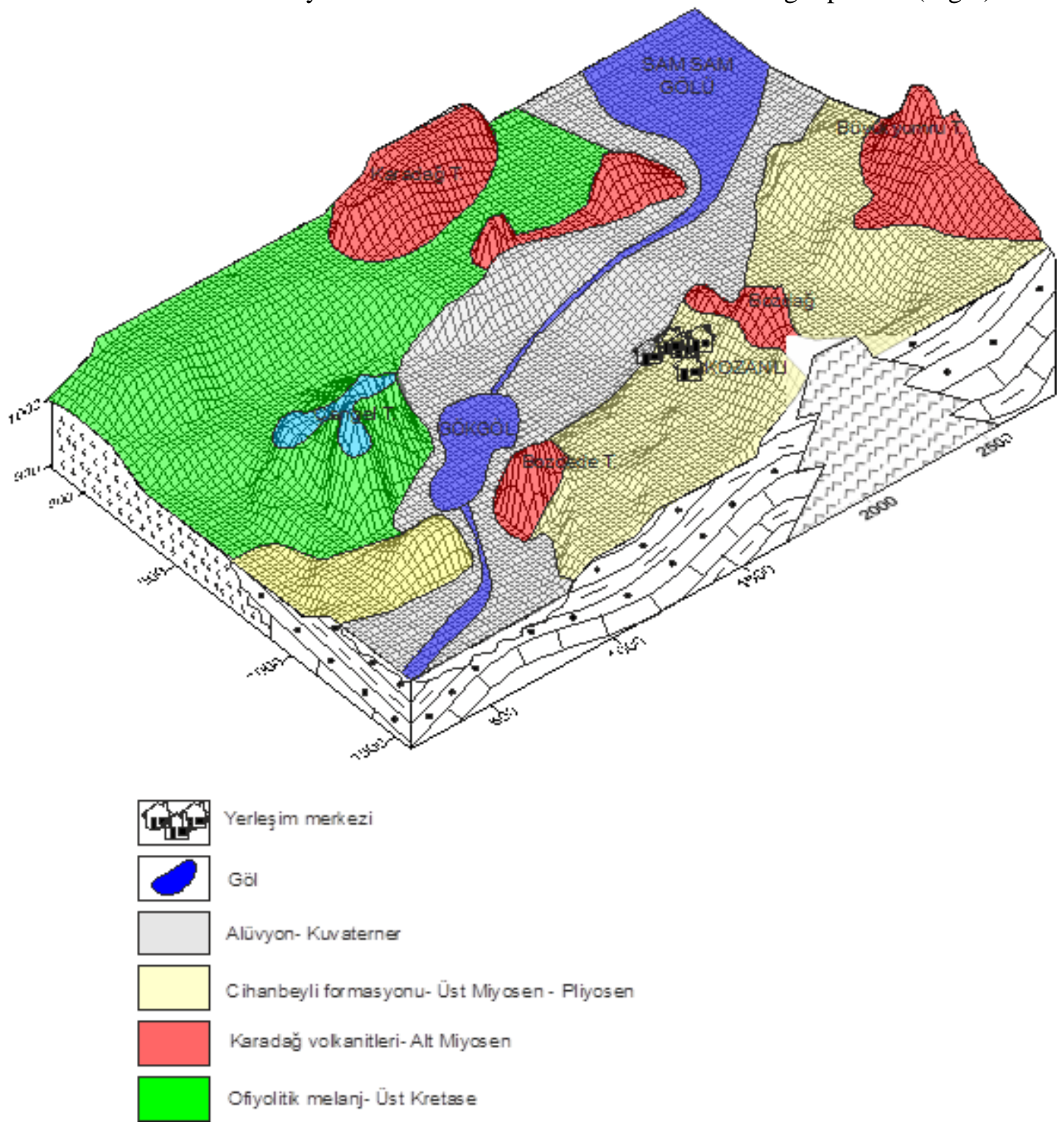

Fig. 7 Digitized black diagram and geology of Gökgöl and its environment

\subsection{Hydrogeological properties of units}

In the study area Gökgöl plateau and its surroundings as the basic unit has impermeable ophiolitic melange olistolitics that are in the units show the nature of aqufuge, they have grained permeability because of their 
fracture fractured feature $[6,7,8]$. Especially in Çengeldağ Wells that are opened for quarries are operated. \#3 well is one of them. The total working area that is calculated by hydrogen soft computer programme is approximately $142 \mathrm{~km}$ and it covers an area of $26 \mathrm{~km}$ ophiolitic melange. Although Karadağ volcanics have partially water possession feature, they are impermeable characters. These types of volcanics have underground heating so they can have hot water tanks that are covered geopressured reservoir Karadağ Volcanics area was determined to be $22 \mathrm{~km}$ Cihanbeyli Formation that becomes clastic sedimentary rocks shows the aquifer feature but the thin rocks among the large ones and rocks are like main make this formation has $337 \mathrm{~km}$ mostra.

In the studying area, covering a large area of $61.1 \mathrm{~km}$ alluvial materials that have permeability features, their natures carry aquifer. Especially in the eastern part of Gökgöl area groundwater is quite close to surface. Thus, although Gökgöl plateau has the nature of $96.8 \mathrm{~km}$ aquifer, the area of $48 \mathrm{~km}$ covers the area that has aquifuge and akiklüd features.

\subsection{Flowing of Groundwater and Its Directions}

The study area that includes Gökgöl plateu and Kozanlı settlement and also its environment has 23 Wells. Their groundwater level has been come up by the help of well owness. Especially ophiolite melange that is in the southwest of the platue is an impermeability basic unit so the number 3 wel has been opened in this area hasn't been taken into consideration.

The water level measurements were taken from 22 wells, izohydnohips was made by the help of surfers programme. As it can be seen in the map of groundwater, groundwater flow is moving towards Kozanl1 settlement and the south and mostly the northeast of Gökgöl plateau (Fig 8).

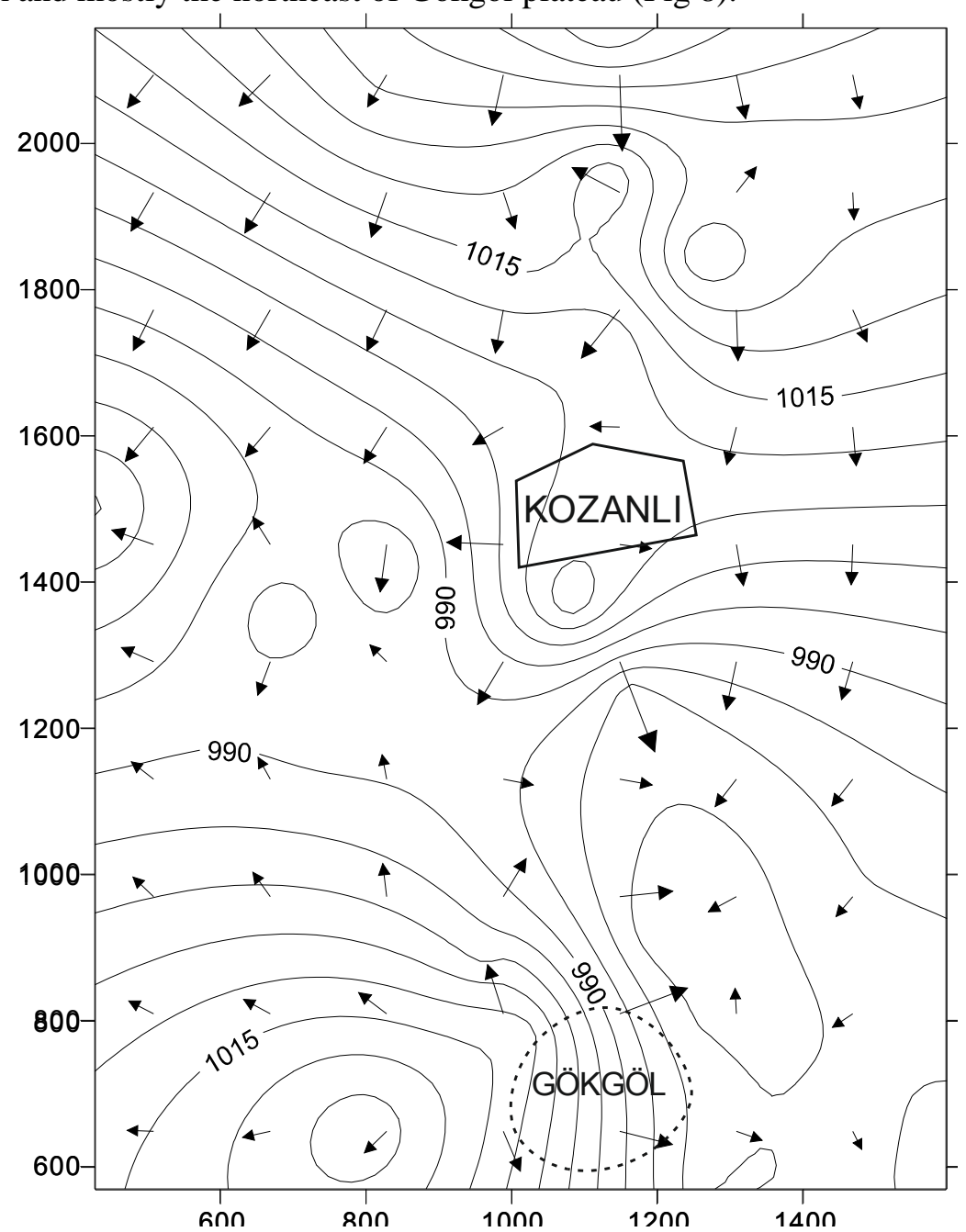

Fig 8 Izohydrohips curves that belong to Gökgöl and its surrounding and groundwater flow directions 


\section{References}

[1] Asan, K., 2002. Karacadağ (Kulu-Konya) yöresi volkanik kayaçlarının petrografik ve jeokimyasal incelemesi. Selçuk Üniversitesi, Konya, Yüksek Lisans Tezi, 111s.

[2] Çemen, İ., Göncüoğlu, M.C. and Dirik, K., 1999. Structural evolution of the Tuzgölü basin in Central Anatolia, Turkey. The Journal of Geology, 107, 693-706.

https://doi.org/10.1086/314379

[3] Ercan, T., 1987. Orta Anadoludaki Senozoyik volkanizması. MTA derg., 107, 119-140.

[4] Ercan, T., Fujitanu, T., Matsuda, J.C., Tokel, S., Notsu, K., Ul, T., Can, B., Selvi, Y., Yıldırım, T., Fişekçi, A., Ölmez, M., Akbaşlı, A., 1990. Hasandağı-Karacadağ (Orta Anadolu) dolaylarındaki Senozoyik yaşlı volkanizmanın kökeni ve evrimi. Jeomorfoloji Derg., 18, 39-54.

[5] Eren, Y., Kurt, H., Rosselet, F., Stampfli, G.M., 2004. Paleozoic deformation and magmatism in the northern area of the Anatolide block (Konya), witness of the Palaeotethys active margin. Eclogae Geol. Helv. 97, 293-306.

https://doi.org/10.1007/s00015-003-1131-8

[6] Keller, J., 1974, Quaternary maar volcanism near Karapınar in Central Anatolia. Bull. Volcan., 38/2, 378-396. https://doi.org/10.1007/BF02599413

[7] Seyitoğlu, G., Scott, B.C., 1992. Late Cenozoic volcanic evolution of the northeastern Aegean region. J. Volcanol. Geotherm. Res. 54, 157-176.

https://doi.org/10.1016/0377-0273(92)90121-S

[8] Uğuz, M.F., Turhan, N., Bilgin, A.Z., Umut, M., Şen, A.M., Acarlar, M., 1999. Kulu (Konya), Haymana (Ankara) ve Kırıkkale dolayının jeolojisi. MTA Der. Rap. No: 10399. 